Int. J. Electrochem. Sci., 11 (2016) $7461-7474$

\title{
Synergistic Effect of Iron Bacteria and Vibrio on Carbon Steel Corrosion in Seawater
}

\author{
Rui $\mathrm{Ke}^{1,2}, \mathrm{Ke}_{\mathrm{CHAI}}{ }^{1, *}$ and Jinyi $W U^{1,3, * *}$ \\ ${ }^{1}$ Key Laboratory of Ministry of Education for Advanced Materials in Tropical Island Resources, \\ Material and Chemical Engineering College, Hainan University, Haikou 570228, China \\ ${ }^{2}$ Nuclear Technology and Chemistry \& Biology College, Hubei Institute of Science and Technology, \\ Xianning 437100, China \\ ${ }^{3}$ Key Laboratory of Marine Environmental Corrosion and Bio-fouling, Institute of Oceanology, \\ Chinese Academy of Sciences, Qingdao 266071, China \\ *E-mail: chaike888@ sina.com \\ ***mail: wujinyi1976@163.com
}

doi: $10.20964 / 2016.09 .27$

Received: 30 September 2015 / Accepted: 18 November 2015 / Published: 7 August 2016

The microbiologically influenced corrosion and electrochemical behavior of 45 steel were investigated in the presence of vibrio and iron bacteria using the mass loss determination, electrochemical analysis method and surface analysis method. The results showed that the corrosion of 45 steel was accelerated for the presence of the two bacterial species. 45 steel immersed in mixed medium containing both vibrio and iron bacteria showed a lower free corrosion current potential and a decrease in impedance with immersion time. Scanning electron microscopy (SEM) revealed that the mixed bacteria system caused more severe pitting corrosion of carbon steel.

Keywords: Microbiologically influenced corrosion; Vibrio; Iron bacteria; Synergistic effect

\section{FULL TEXT}

(C) 2016 The Authors. Published by ESG (www.electrochemsci.org). This article is an open access article distributed under the terms and conditions of the Creative Commons Attribution license (http://creativecommons.org/licenses/by/4.0/). 